Далее речь пойдет об анализе сочинения на тему по специальности. Выбор обусловлен наличием опыта работы в техническом вузе и наличием практического опыта в их проведении.

На первый взгляд работы по теме специальности во многом близки к сочинениям на свободную тему. Они нужны и полезны нашим студентам, поскольку развивают навыки, необходимые им в непосредственной работе на факультетах. Они помогают накоплению и активизации специальной лексики, введению в практику грамматических конструкций современной научной речи, способствуют развитию навыков цитирования, конспектирования и обобщения книжного и лекционного материала. Темы работы по специальности сначала формулируются в общем виде, позже ограничиваются и конкретизируются. Написание данного вида работы по одновременно может контролировать знания студентов в области специальности и может вводить необходимый для студентов лексический и грамматический материал. Оба варианта применимы и полезны на всех этапах обучения, включая выпускной экзамен. Материалы для работы: специальные тексты по специальности, научнопопулярная литература, материалы конференций по направлению подготовки и т.п. во время подготовительного этапа работы особое место уделяется работе синтаксисом научной речи.

Подводя итоги, можно сделать следующие выводы:

1. определенное место в системе занятий по русскому языку со студентамииностранцами занимают творческие письменные работы.

2. Творческие письменные работы после планирования, подготовки и анализа служат действенным и активным средством для скорейшего и прочнейшего усвоения материала.

3. Как показывает опыт, написание данного вида работ позволяет контролировать пополнение словарного запаса специализированной лексики инженера.

$$
* * *
$$

1. А. Н. Барыкина, В.П. Бурмистрова, В.В. Добровольская, Пособие по развитию навыков письменной речи. - Москва: Русский язык, 1978.

2. Проблемы преподавания филологических дисциплин иностранным учащимся : : Материалы 4-й Международной научно -методической конфе- ренции. - Воронеж : ИПЦ «Научная книга», 2016. $467 \mathrm{c.}$

\title{
Сергеева С.H. \\ Формирование читательской компетенции учащихся на уроках литературы в основной школе
}

МБОУ"СОШ №37

doi: $10.18411 / s p c-25-01-2018-05$

(Россия, Набережные Челны)

idsp: 000001:spc-25-01-2018-05

\section{Аннотация}

Задача данной статьи - ознакомить читателя с понятиями "читательская грамотность", "читательская компетентность"; показать методики формирования читательской компетентности.

Ключевые слова: школа, учебная деятельность; читательская грамотность, читательская компетентность; методики формирования читательской компетентности.

\section{Abstract}

The task of this article is to acquaint the reader with the concepts of "literacy", "reader competence"; show methods of forming the reader's competence.

Key words: school, educational activity; reader literacy, reading competence; methods of forming reader competence. 
Если учитель соединяет в себе любовь к делу и к ученикам, он совершенный учитель. Лев Толстой

Современное общество ставит перед образовательными учреждениями задачу подготовки человека думающего, выпускника, способного активно участвовать в созидательной жизнедеятельности, проявлять инициативу, независимость и ответственность. В решении этой задачи важнейшую роль играет художественная литература. Обучение чтению является неотъемлемой частью общего образования человека. Именно чтение представляет собой важнейший способ освоения и поддержания любого жизненно важного знания (в том числе и профессионального).

И ответственность за это несут родители и ,несомненно, учителя русского языка и литературы.

Каждый учитель литературы, работающий в школе, сталкивается с проблемой восприятия учащимися художественных произведений. Связано это с тем, что учащиеся считают учебный предмет "Литература" таким же обычным, как и всякий другой предмет, некоторые считают его совершенно бесполезным. Мнение учащихся подтверждает расхожий упрек в адрес нынешнего урока литературы. Он не возбуждает интереса к чтению. То, что изучаемая литература не читается детьми, рассматривается нынче как само собой разумеющееся явление. Самостоятельное чтение детей идет по одному руслу, изучаемое - совсем по другому. Изучение литературы, как и сам урок литературы, оказались оторванными от реального чтения и интересов детей и подростков. Великие произведения Великой литературы оказываются невостребованными, потому трудно не согласиться с утверждением ученого-методиста Розы Ивановны Альбетковой: «Задача учителя-словесника - воспитание компетентного читателя».

В связи с вышесказанным, понятно, что нужно изменить преподавание литературы в школе, чтобы повысить читательскую грамотность, чтобы учащиеся на классической литературе, персонажах учились преодолевать трудности, находить выход из любой ситуации, оставаясь при этом человеком. Для этого необходимо формировать читательскую компетенцию.

\section{Понятие читательской компетентности.}

По определению «читательская грамотность» понимается как способность к осмыслению письменных текстов и рефлексии на них, способность использовать их содержание для достижения различных целей. Овладеть читательской грамотностью это значит понимать текст, размышлять над его содержанием, оценивать его смысл и значение, излагать свои мысли о прочитанном.

Понятие «читательская компетентность» имеет более широкий смысл. Определяя читательскую компетентность, можно сказать, что это качество сохранения прочитанного, сформированное на основе общей культуры человека, обеспечивающее возможность решения возникающих учебно-академических, социальных, a впоследствии и профессиональных задач адекватно ситуациям в широком социальном взаимодействии и образовательно-профессиональной деятельности.

Выделяют следующую структуру читательской компетентности, которая состоит из следующих компонентов:

Познавательный - знания (степень их обобщения и полноты);

Операционально-технологический - умения (степень свернутости и освоенности, возможность переноса выполняемых действий);

Ценностно-смысловой - ценностно-смысловые ориентации (отношение к процессу, содержанию и результату деятельности).

Читательская компетентность формируется семьей, дошкольными учреждениями, школой, профессиональными средними и высшими учебными 
заведениями и учреждениями культуры. Она является результатом воспитания, обучения и образования. При этом читательская компетентность основывается как на развитии мыслительных действий и механизмов чтения, так и на развитии личностных качеств учащихся. Именно эту развивающую составляющую хотят видеть в любой программе по чтению сторонники личностно-ориентированного обучения, поборники чтения великой русской классики как источника нравственного становления личности.

Однако читательская компетентность имеет и деятельностную составляющую, которая формируется в образовательном процессе применительно к задачам каждой его ступени, основывается на междисциплинарных, межпредметных знаниях и осуществляется через множество умений - искать и анализировать информацию, понимать и интерпретировать текст, оценивать и формировать суждения о тексте (рефлексивность).

\section{Методики формирования читательской компетентности}

Развитию читательской компетентности способствует использование на занятиях элементов современных образовательных технологий: технологии проблемного обучения, технологии интегрированного обучения, игровых технологий, информационных технологий.

Мы видим, что наряду со специальными приемами работы с текстом художественного произведения, составляющими содержание уроков литературы, существуют универсальные приемы работы с текстом, способствующие осмысленному отношению к тексту.

Освоение технологии продуктивного чтения связано с реализацией принципа управляемого перехода от деятельности в учебной ситуации к деятельности в жизненной ситуации. В процессе работы с текстом ученик выстраивает не только диалог с автором как носителем художественной идеи, но и с учителем, вполне реальным человеком со сложившимся мировоззрением. Учитель и ученик становятся равноправными участниками диалога культур, а это уже позволяет говорить о создании модели взаимоотношений мира и человека. Именно такой подход заложен в новых образовательных стандартах и определяет содержание компетентностного подхода.

\section{Приемы формирования читательской компетенции ПРИЁМ «РОМАШКА»}

Каждая группа по тексту составляет для другой группы свои вопросы:

- 1 группа Простые вопросы

- 2 группа Уточняющие вопросы.

- 3 группа Объясняющие вопросы

- 4 группа Оценочные вопросы

- 5 группа Практические вопросы

Пример. Рассказ В.П Астафьева «Зачем я убил коростеля?»

- 1 группа Простые вопросы (Как и где герой рассказа встретил коростеля?)

- 2 группа Творческие вопросы (Если бы вы были художником, какую картину нарисовали к этому рассказу?)

- 3 группа Объясняющие вопросы (Почему герой рассказа даже спустя годы помнит о своем поступке?)

- 4 группа Оценочные вопросы ( Как вы относитесь к поступку героя рассказа?)

- 5 группа Практические вопросы (Как бы вы поступили на месте героя рассказа?)

\section{ПРИЕМ «ЦВЕТОПИСЬ»}

Приемы психорисунка дают возможность выразить понимание абстрактных понятий, внутренний мир через зрительные образы. 
Задание: нарисовать характер героя (совесть, месть, добро, зло и т.д) и объяснить рисунок.

\section{ПРИЕМ «ИГРА НАОБОРОТ».}

Задание: Преобразуйте стихотворение в прозу/прозу в стихотворение, используя приемы речевой выразительности

\begin{tabular}{|c|c|}
\hline Стих Б.Л Пастернака & Сочинение ученицы 9в \\
\hline $\begin{array}{l}\text {...Но нежданно по портьере } \\
\text { Пробежсит сомненья дрожь, - } \\
\text { Тишину шагами меря. } \\
\text { Ты, как будущность, войдёшь. } \\
\text { Ты появишься из две́ри } \\
\text { В чём-то белом, без причуд, } \\
\text { В чём-то, впрямь из тех материй, } \\
\text { Из которых хлопья шьют. } \\
\text { • } \quad \text { Б.Л.Пастернак }\end{array}$ & $\begin{array}{l}\text { • По холодному паркету шла Она, беззвучно } \\
\text { ступая босыми ногами. Мужчна почувствовал } \\
\text { прикосновение. Оно было легким, почти } \\
\text { призрачным, как видение. Но он поднял лицо и } \\
\text { застыл. Нет слов, которые бы смогли описать } \\
\text { это... } \\
\text { • } \quad \text { Бельии сарафан, сотканный из чистейшего } \\
\text { снега и несбывшихся мечтаний, светлье волосы и } \\
\text { призрачно-бледная кожа. Лик ее всегда мелькал } \\
\text { где-то рядом. Но ярким образом проявлялся } \\
\text { только перед грустньми людьми. Им нужна была } \\
\text { надежса. Она и была надеждой. Холодное утро } \\
\text { января подарило ему Надежду, ту самую } \\
\text { прекрасную надежду, которая только могла } \\
\text { появиться у этого мужчинь. И ее образа было } \\
\text { достаточно, чтобы влюбиться в жизнь. }\end{array}$ \\
\hline
\end{tabular}

\section{Ханнанова Д.М. \\ Модальная категория необходимости}

Казанский инновационный университет им. В.Г. Тимирясова (ИУЭП), филиал

(Россия, Альметьевск)

doi: $10.18411 / s p c-25-01-2018-06$

idsp: 000001:spc-25-01-2018-06

Изучению модальности в целом и ее частных разновидностей посвящено множество научных работ. Интерес к ее исследованию не ослабевает в связи с повышенным вниманием к роли языка как средства коммуникации и индивидуализации мыслительно-речевого процесса человека. Актуальность поднимаемой проблемы созвучна также с общей тенденцией усовершенствования, упорядочения и систематизации понятийно-терминологического аппарата лингвистической науки, поскольку субъектная модальность, обладая многоплановостью семантики, разнообразными средствами выражения и множественностью возможных соотношений между формой и содержанием в процессе речевого функционирования [5, с. 3], обусловливает появление в науке различных, часто противоречивых и запутанных интерпретаций категории. Не исключением является и модальность необходимости, котораярассматривается не только в системевзаимосвязей общих модальностей возможности, действительности, случайности, но и в системе личных модальностей индивидуума - желательности, потребности, вынужденности, побудительности и т.д.

Особенно непоследовательно и противоречиво в лингвистической литературе освещается вопрос о соотношении категорий необходимости и долженствования. Одни исследователи отмечают взаимопроницаемость указанных категорий, их содержательную близость и семантическое родство. Другим, они видятся как взаимообусловленные, когда долженствование относится к необходимости как частное к общему. Третьи утверждают, что категории долженствования и необходимости являются категориями самостоятельными исамодостаточными. Причина в 